\title{
Campur Kode dan Alih Kode pada Proses Belajar Mengajar
}

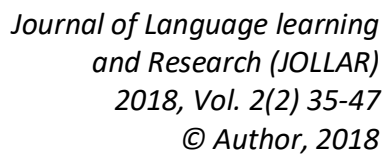

Journal of Language learning and Research (JOLLAR) 2018, Vol. 2(2) 35-47

(C) Author, 2018

DOI: 10.22236/JOLLAR_2(2)35-47

\section{Eka Nurul Mualimah ${ }^{1}$}

\section{STKIP Setia Budhi Rangkasbitung}

Penelitian ini berkenaan dengan adanya perkembangan bahasa yang terjadi pada masyarakat khususnya Mahasiswa STKIP setia Budhi Rangkasbitung yang bilingual, mengakibatkan adanya campur kode dan peralihan kode. Permasalahan yang diteliti dalam penelitian ini berkenaan dengan, (1) bentuk campur kode, (2) bentuk alih kode, dan (3) faktor penyebab terjadinya campur kode dan alih kode. Metode yang dipergunakan adalah deskriptif kualitatif, yaitu suatu metode yang menginterprestasikan fenomena-fenomena yang terjadi pada tuturan Mahasiswa. Hasil peneltian menunjukan, bahwa dalam proses pembelajaran ditemukan 4 pencampuran kode dengan bentuk campur kode internal dan campur kode eksternal. Campur kode yang dilakukan Mahasiswa semester 1 dalam kegiatan belajar di temukan 11 serpihan kata. Faktor yang mempengaruhi campur kode dan alih kode yang dilakukan mahasiswa dan dosen kesulitan mencari padanan kata, kebiasaan, kesombongan, topik pembicaraan, hadirnya pihak ketiga, dan menghormati

Kata kunci : Ali Kode, Campur Kode, Faktor Penyebabnya

This study dealt with the language development that happened multilingually at STKIP Setia Budhi Rangkasbitung. The bilingual language itself caused the code mixing and code switching in the daily language. This research touched some points: (1) the nature of code mixing, (2) the nature of code switching, (3) the influential factors causing code mixing and code switching. The method used in this research was qualitative method. The results found 4 mixing codes with the form of mixed internal code and mixed external code. Mixing codes found in semester 1 in the learning activities found were 11 pieces of words. Factors affecting code mixing and code transfer by students and lecturers were difficult synonym finding, habits, pride, topics of conversation, presence of third parties, and respect

Keyword : Code mixing, code Switching, and factors influences

\footnotetext{
${ }^{1}$ Corresponding author: eka88nurul@gmail.com
} 


\section{PENDAHULUAN}

Bahasa sebagai salah satu unsur budaya yang tidak terlepas dari kemajemukannya. Di Indonesia dikenal bahasa Indonesia dan beraneka ragam bahasa daerah. Bahasa daerah dipergunakan sebagai alat komunikasi antar suku bangsa itu sendiri, sedangkan untuk berkomunikasi dengan suku bangsa yang lainya digunakan bahasa Indonesia sebagai alat pemersatu bangsa.

Masyarakat Indonesia pada umumnya termasuk masyarakat yang menguasai lebih dari satu bahasa. Hampir semua suku bangsa di Indonesia memiliki bahasa Ibu atau bahasa pertama (B1), bahasa daerah. Di samping itu pengusaan terhadap bahasa kedua(B2), yaitu bahasa Indonesia. bahkan kelompok masyarakat Indonesia yang terpelajar dapat menguasai lebih dari dua atau tiga bahasa, yaitu bahasa daerah, bahasa Indonesia dan bahasa Asing. Dengan demikian, masyarakat Indonesia dapat dikelompokan sebagai masyarakat yang bilingual bahkan multi bahasawan.

Masyarakat bilingual atau multi lingual yang menguasai lebih dari satu bahasa akan melakukan peristiwa kontak bahasa. Kontak bahasa itu terjadi antara bahasa yang satu dengan bahasa yang lain. Akibat dari pristiwa kontak bahasa itu akan timbul dalam dua hal, yaitu campur kode dan alih kode.Alih kode dan campur kode merupakan salah satu fenomena dalam interaksi sosial yang terjadi pada masyarakat bilingual atau multilingual.

Melihat kenyataan bahwa di STKIP Setia Budhi Rangkasbitung merupakan komunitas bilingual dengan bahasa pertamanya bahasa Sunda dan bahasa kedua dengan bahasa Indonesia, maka tidak jarang ditemui Mahasiswa yang berbahasa lebih dari satu bahasa. Kesanggupan seseorang menggunakan lebih dari satu bahasa tersebut disebabkan oleh keinginan untuk saling berkomunikasi antara yang satu dengan yang lainya, dan penguasaan bahasa lebih dari satu mendorong Mahasiswa untuk menentukan pilihan bahasa yang akan digunakan dalam berkomunikasi.

Penggunaan suatu kode pada situasi resmi terutama dalam proses belajar mengajar ditekankan pada satu variasi bahasa dalam satu bahasa tetapi tidak menutup kemungkinan Mahasiswa dalam bertutur menggunakan serpihanserpihan dari bahasa lain. Hal itu dapat terjadi karena bahasa Ibu sangat berpengaruh terhadap bahasa kedua, seperti ungkapan Ellis (Chaer,2004:256) bahwa bahasa pertama (bahasa ibu) mempunyai pengaruh terhadap proses penguasaan bahasa kedua. Hal ini karena terbiasa terjadi secara sadar atau tidak melakukan transfer unsur-unsur bahasa pertamanya ketika menggunakan bahasa kedua akibatnya terjadi alih kode dan campur kode. Hal lain yang dapat mempengaruhi adalah globalisasi kemajuan ilmu pengetahuan. Arus informasi yang sangat cepat menuntut seseorang menguasai bahasa internasional yaitu bahasa Inggris. Penguasaan bahasa internasional ini dapat mengakibatkan terjadinya peralihan kode keluar. Pengusaan beberapa bahasa tersebut dapat mendorong 
Mahasiswa menggunakan berbagai bahasa dalam situasi dan tujuan yang berbeda. Tidak dapat dihindari hampir tidak mungkin bagi seorang pemakai bahasa dalam masyarakat bilingual dan masyarakat multi lingual untuk menggunakan satu bahasa saja tanpa terpengaruh bahasa lain meskipun hanya sejumlah kosakata saja.

Penggunaan kode bahasa dapat dipengarui oleh faktor sikap. Sikap merupakan sesuatu yang diperoleh seseorang melalui interaksi dengan suatu objek sosial atau peristiwa sosial. Sikap tidak dibawa sejak lahir, melainkan dibentuk melalui proses belajar di dalam suatu konteks sosial tertentu. Oleh karena itu sikap dapat dipelajari dan dibentuk melalui interaksi dengan objek sosial atau peristiwa sosial. Karena itu sikap dapat berubah, diubah atau dikembalikan seperti semula walaupun dalam waktu yang lama. Perubahan sikap tersebut juga disebabkan oleh adanya stimulus (Rainforcement) pada saat terbentuknya sikap.

Berdasarkan latar belakang tersebut, kajian ini dibatasi pada gejala kontak bahasa yang berupa campur kode dan alih kode dalam bahasa lisan Dosen dan Mahasiswa pada semester 1. Sedangkan rumusan masalah yang dikaji adalah bagaimana bentuk campur kode dan alih kode dalam penggunaan bahasa Indonesia ragam lisan pada proses pembelajaran yang dilakukan Dosen dan Mahasiswa semester 1 STKIP Setia Budhi Rangkasbitung? Penelitian ini bertujuan untuk mengetahui bentuk campur kode dan alih kode yang dilakukan Dosen dan Mahasiswa semester 1, serta menganalisis percakapan Dosen dan Mahasiswa untuk mengetahui faktor lain yang menyebabkan terjadinya campur kode dan alih kode.

Penelitian ini di harapkan menambah wawasan keilmuan di bidang sosiolinguistik khususnya bidang kedwibahasawan. Selain itu, pemerolehan hasil analisis campur kode dan alih kode bahasa daerah terhadap penggunaan bahasa Indonesia baik kosakata, struktur frasa maupun klausa diharapkan memberikan gambaran tentang kualitas Dosen dan Mahasiswa dalam berbahasa Indonesia dan dijadikan tolak ukur untuk meningkatkan kemampuannya dalam berbahasa Indonesia.

Teori yang dipergunakan dalam penelitian ini adalah bilingualisme. Bilingualisme menurut Chaer dan Agustina (2004: 84) adalah penggunaan dua bahasa oleh seorang penutur dalam pergaulannya dengan orang lain secara bergantian. Untuk dapat menggunakan dua bahasa tentunya seseorang harus menguasai kedua bahasa itu. Pertama, bahasa ibunya sendiri atau bahasa pertamanya (B1), dan yang kedua adalah bahasa lain yang menjadi bahasa keduanya (B2). Orang yang dapat menggunakan kedua bahasa disebut orang yang bilingual dalam bahasa Indonesia disebut juga dwibahasawan. Kemampuan untuk menggunakan dua bahasa disebut bilingualitas dalam bahasa Indonesia disebut juga kedwibahasawanan.

Penguasaan atas paling tidak dua bahasa, yakni bahasa pertama dan bahasa kedua. Adapun yang dimaksud dengan menguasai dalam tulisan ini bahwa 
menguasai sampai pada keadaan yang paling rendah kadarnya, bahkan dapat dikatakan baru sampai tahap mengenal saja. Penentuan batasan bilingualisme yang demikian itu pada hemat peneliti benar-benar menunjuk pada realita. Artinya, bahwa kadar penguasaan bahasa yang bukan bahasa ibu, tidak pernah akan dapat sama dengan kadar penguasaan bahasa pertamanya. Maka yang dimaksud dengan penggunaan dua bahasa oleh penutur adalah kebiasaan penutur bilingual menggunakan bahasa pertama (B1) yaitu dalam bahasa Sunda yang digunakan dan bahasa kedua (B2) dalam bahasa Indonesia sebagai interaksi dengan orang lain yang tentunya disesuaikan dengan situasi lingkungan kebiasaannya.

Apabila bahasa merupakan milik kelompok, maka kedwibahasaan milik perseorangan atau individu para penutur, sebab penggunaan bahasa secara bergantian oleh seorang penutur yang bilingual mengharuskan adanya dua masyarakat tutur yang berbeda, misalnya masyarakat tutur BI dan masyarakat tutur B2.

Melihat masalah penggunaan dua bahasa atau lebih oleh masyarakat tutur yang berdwibahasawan, yakni dua bahasa atau lebih tersebut digunakan sebagai alat untuk berkomunikasi antara punutur dengan lawan tuturnya sebagai alat komunikasi. Namun, dapat kita ketahui bahwa tidak dapat seseorang mengerjakan kebiasaan dalam menggunakan dua bahasa untuk berinteraksi dengan lawan tuturnya tanpa penutur tersebut mempunyai kemampuan dalam menggunakan dua bahasa. Maksudnya bahwa secara logika seseorang yang mempunyai kebiasaan menggunakan dua bahasa dalam komunikasinya, maka dapat dipastikan seseorang tersebut mempunyai kemampuan dalam hal menggunakan dua bahasa yang digunakannya untuk berkomunikasi dengan lawan tuturnya.

Penguasaan lebih dari satu bahasa dalam melakukan komunikasi dengan lawan tutur akan mengakibat campur kode dan alih kode. Alih kode dan campur kode merupakan salah satu fenomena dalam interaksi sosial yang terjadi pada masyarakat bilingual atau multilingual.

\section{Campur Kode}

Campur kode menurut Chaer dan Agustina (2004: 114) adalah pencampuran serpihan kata, frasa, dan klausa suatu bahasa di dalam bahasa lain yang digunakan. Satu bahasa yang digunakan di dalamnya terdapat serpihan-serpihan dari bahasa lain. Seorang penutur misalnya, dalam berbahasa Indonesia banyak menyelipkan bahasa daerahnya, maka penutur itu dapat dikatakan telah melakukan campur kode. Peristiwa campur kode dilatarbelakangi oleh peristiwa terjadinya campur kode yaitu terjadi tanpa sebab. Dalam campur kode ini dua kode atau lebih digunakan barsama tanpa alasan, dan terjadi dalam situasi santai. Dalam situasi formal terjadi juga campur kode, maka biasanya karena ketiadaan ungkapan yang harus digunakan dalam bahasa yang sedang dipakai. Dalam masyarakat Indonesia kasus 
campur kode ini biasa terjadi. Biasanya dalam berbicara dalam bahasa Indonesia dicampurkan dengan unsur-unsur bahasa daerah. Sebaliknya juga terjadi dalam berbahasa daerah tercampur unsur-unsur bahasa Indonesia.

Peristiwa tutur yang terjadi akibat adanya klausa-klausa dan frasa-frasa yang digunakan oleh penutur yang terdiri dari klausa dan frasa campuran dan masing-masing klausa dan frasa itu tidak lagi mendukung fungsi sendiri-sendiri (Aslinda dan Syafyahya.2007: 87). Artinya, bahwa dalam campur kode dapat dipahami sebagai pemakaian dua bahasa atau lebih dengan saling memasukan unsur-unsur bahasa atau lebih dengan saling memasukan unsur-unsur bahasa yang satu ke dalam bahasa yang lain secara konsisten. Suwito (1983: 68) menjelaskan dua jenis campur kode, yaitu :

1. Campur kode bersifat kedalam

Campur kode bersifat kedalam apabila fenomena ini menunjukan bahwa unsurunsur bahasanya masih tergolong satu kerabat. Campur kode kedalam sama dengan campur kode internal. Contoh campur kode kedalam (campur kode internal) dalam dialog subagai berikut

Uni : Kak tolong candakeun minum

Firman : Iya, nanti.

Kata candakeun adalah bentuk campur kode yang sebenarnya masih dapat dihindari sebab kata tersebut sudah ada padanannya dalam bahasa Indonesia. Kata candakeun adalah bahasa Sunda yang hidup dalam wilayah serumpun, maka hal itu dikatakan campur kode.

2. Campur kode bersifat keluar

Campur kode bersifat keluar apabila unsur-unsur tidak sekerabat. Campur kode bersifat keluar sama halnya dengan campur kode eksternal. Campur kode eksternal adalah kode yang terjadi antara kode sendiri dengan bahasa asing atau tidak serumpun, seperti bahasa Indonesia beralih kepada bahasa Inggris atau sebalikanya dari bahasa Inggris ke bahasa Indonesia. Campur kode dapat diilustrasikan sebagai berikut

Faris : Hari ini jadi bertemu di kampuskan? harus On time ya di depan kampus!

Eka : Iya Insyallah.

Kata On time yang dituturkan Faris adalah bentuk campur kode karena terjadi pencampuran bahasa Indonesia dengan bahasa Inggris. Tetapi berbeda dengan tuturan Eka yang mencampurkan bahasa Indonesia dengan bahasa Arab

Penjelasan di atas maka penulis dapat mengambil kesimpulan bahwa campur kode adalah fenomena yang terjadi karena masuknya serpihan unsur suatu bahasa ke dalam bahasa lain. Hal itu tidak berarti bahwa tidak ada sebab terjadinya campur kode. Ada kemungkinan campur kode terjadi karena faktor individu, seperti ingin menunjukan status, peran, dan kepakaran. Ada juga kemungkinan sebab 
kurangnya unsur bahasa yang sedang digunakan. Selain itu, campur kode terjadi jika dalam suatu peristiwa tutur klausa-klausa dan frasa-frasa yang digunakan terdiri dari klausa dan frasa itu tidak lagi mendukung fungsi sendiri-sendiri, maka peristiwa yang terjadi adalah campur kode.

\section{Alih Kode}

Selain terjadi percampuran kode, dwibahasaan dalam ujaranya akan sering mengganti kode bahasa atau ragam bahasa yang disebut alih kode. Pergantian kode tersebut disebabkan oleh situasi atau keperluan dalam bahasa.

there is a situation where speakers deliberately change a code being used, namely by switching from one to another, the change is called code switching. Code switching is found more with bilingual or multilingual. Code switching is the use of more than one language by communicants in the execution of a speech act. (Indrawan, Made.2010:74)

Penjelasan Indrawan tersebut mengatakan bahwa alih kode dapat terjadi pada masyarakat bahasa bilingual atau multilingual. Dalam keadaan bilingual atau multilingual, penutur ada kalanya mengganti unsur-unsur bahasa atau tingkat tutur, hal ini tergantung pada konteks dan situasi berbahasa tersebut. Misalnya, ketika berbahasa Jawa dengan si A, datang si B yang tidak dapat berbahasa Jawa memasuki situasi berbahasa itu, maka kita beralih memakai bahasa yang dimengerti oleh si B yaitu bahasa Indonesia sebagai bahasa persatuan.

Poedjosoedarmo (Rahardi, 2010 : 24) menjelaskan bahwa seseorang sering mengganti kode bahasanya pada saat bercakap-cakap. Pergantian itu dapat disadari atau bahkan mungkin pula tidak disadari oleh penutur. Penutur tersebut memasukan unsur bahasa lain ke dalam bahasa yang sedang digunakannya karena sebab lain. Misalnya, karena menginginkan suasana kesantaian dalam bertutur atau karena bahasa yang digunakannya tidak memiliki ungkapan untuk konsep yang akan dikemukakannya, sehingga perlu memakai kata atau ungkapan dari bahasa daerah. Menurut Hymes dikutip oleh Rahardi (2010:20) menyebutkkan jenis alih kode yaitu alih kode internal dan, alih kode eksternal.

1. Alih kode internal adalah alih kode yang terjadi antar bahasa dalam suatu bahasa nasional, antar dialek dalam suatu bahasa daerah, atau antar beberapa ragam dan gaya yang terdapat dalam suatu dialek, contohnya:

$\begin{array}{ll}\text { Pedagang } & : \text { Jaman kiwari hese nyiar duit? (jaman sekrang } \\ & \text { susah ya pak, cari uang?) } \\ \text { Tukang becak } & : \text { Muhun,hese nyiar jeung emam doang geh } \\ & \quad \text { (iya susah mencari untuk makan) } \\ \text { Pedagang } & : \text { barang-barang mahal } \\ \text { Calon penumpang } & : \text { Bapak bade narik? (narik tidak pak?) }\end{array}$


Tukang becak

: Muhun Bu narik. (iya bu narik)

Percakapan di pasar yang dilakukan oleh ketiga orang tersebut adalah alih kode internal yaitu dari bahasa Sunda kasar ke bahasa Sunda halus. Yang dilakukan tukang becak beralih kode dari bahasa Sunda kasar (Muhun,hese nyiar jeung emam doang geh) ke bahasa Sunda halus (Muhun Bu narik) karena kehadiran orang ketiga yaitu terhadap calon penumpang.

2. Alih kode eksternal terjadi ketika penutur beralih dari bahasa asalnya ke bahasa asing misalnya dari bahasa Indonesia ke bahasa Arab atau sebaliknya. Contoh di bawah ini tuturan alih kode dari bahasa Indonesia ke dalam bahasa Arab.

H.Romli : Anak muda seminggu lagi datang ke mushola $b a$ 'da ashar!

Fandi : Jam berapa pak?

H.Romli : Ba'da ashar.

Fandi $\quad: \mathrm{B} a$ 'da ashar ya. Ok, fine.

Dari cuplikan tuturan di atas dilihat bahwa alih kode dilakukan Haji Romli pada saat ia menjanjikan bertemu kembali dengan Fandi pada minggu depannya. Namun Haji Romli tidak menyebutkan waktunya hanya tempat, yaitu mushola dan ba'da ashar. Fandi menanyakan kembali pukul berapa dia harus di Mushola. Haji Romli tetap menjawab ba'da ashar. Ba'da ashar adalah frasa arab yang artinya setelah sholat ashar. Jadi, arah alih kode diatas adalah dari bahsa Indonesia ke dalam bahasa Arab.

Menurut Fishman dalam Chaer dan Agustina, (2004: 108) mengatakan di samping perubahan situasi, alih kode ini terjadi juga karena beberapa faktor. Faktorfaktor yang menyebabkan terjadinya alih kode antara lain (1) siapa yang berbicara, (2) dengan bahasa apa, (3) kepada siapa, (4) Kapan, dan (5) tujuan apa. Peneliti menarik kesimpulan dari pandangan tersebut bahwa penyebab terjadinya alih kode karena faktor penutur, lawan tutur, konteks pembicaraan, dan tujuan yang hendak dicapai dalam melakukan alih kode

Seorang penutur seringkali melakukan peralihan kode dan pencampuran kode. Seorang penutur terkadang dengan sadar berusaha beralih kode terhadap lawan tuturnya karena sesuatu maksud. Seorang Dosen dalam kegiatan belajar misalnya mengajar dengan menggunakan pengkodean ke bahasa daerah. Seharusnya, Dosen sebagi penutur berbahasa Indonesia karena sedang berada dalam situasi resmi. Namun, penutur ini mengetahui bahwa lawan tuturnya berasal dari daerah yang sama dengannya, maka nampak usaha dari penutur untuk sedapat mungkin beralih kode dengan bahasa daerahnya agar masalah yang sedang dibicarakan akan lebih mudah dipecahkan.

Berdasarkan pendapat di atas, maka dapat disimpulkan bahwa dalam bidang sosiolinguistik dan komunikasi, kode berarti variasi tertentu dalam suatu bahasa, sistem bahasa dalam suatu masyarakat, lambang atau sistem ungkapan yang dipakai 
untuk mengembangkan makna tertentu, termasuk bahasa manusia itu merupakan sejenis kode. Pencampuran dan peralihan kode yang digunakan oleh penutur dalam satu peristiwa komunikasi verbal. Alih kode pada hakikatnya merupakan pergantian bahasa atau dialek. Rujukannya adalah komunitas bahasa (dialek). Para penutur yang sedang beralih kode berasal dari minimum dua komunitas dari bahasa-bahasa (dialek) yang sedang dipraktekan. Gejala peralihan pemakaian bahasa karena berubahnya situasi. Alih kode dapat terjadi pada dimensi antarbahasa, alih kode berupa peralihan ragam yang dipilih dalam suatu bahasa dalam peristiwa komunikasi.

\section{METODOLOGI}

Jenis penelitian ini adalah kualitatif. Penelitian kualitatif adalah prosedur penelitian yang menghasilkan data deskriptif berupa kata-kata tertulis atau lisan dari orangorang dan prilaku yang diamati (Margono, 2009:36). Data deskriptif dipergunakan untuk memecahkan suatu masalah yang aktual dengan jalan mengumpulkan, menyusun, menganalisis, dan menginterpretasikan data. Deskriptif digunakan tidak hanya melakukan deskripsi murni, tetapi juga menjelaskan hubungan, menentukan makna dan menarik kesimpulan. Data dihasilkan setelah peneliti memasuki lapangan dengan sebjek penelitian Mahasiswa STKIP Setia Budhi Rangkasbitung semester 1, sedangkan sumber data dalam penelitian ini yaitu dialog atau ujaran dalam kegiatan pembelajaran yang dilakukan Dosen dan Mahasiswa STKIP Setia Budhi Rangkasbitung

Penelitian ini di lakukan dengan melakukan observasi. Observasi digunakan untuk mengamati secara langsung dan tidak langsung tentang prilaku Dosen dan Mahasiswa dalam pembelajaran di kelas. Dalam penerapan metode observasi ini, peneliti melakukan teknik dasar yaitu sadap, simak libat cakap dan simak bebas libat cakap.

1. Sadap yakni teknik memperoleh data dengan menyadap atau merekam penggunaan bahasa dalam peristiwa tutur yang alami.

2. Teknik simak libat cakap, peneliti ikut berpartisipasi dalam peristiwa tutur dan merekam tuturan tersebut dalam sebuah alat perekam yang disembunyikan sehingga anggota tutur yang lain tidak mengetahui bahwa tuturannya sedang direkam. Hal ini dilakukan untuk mendapatkan tuturan yang alami dan tidak dibuat-buat.

3. Teknik simak bebas libat cakap, peneliti tidak ikut berpartisipasi dalam peristiwa tutur, namun hanya mendengarkan, mencatat hal-hal yang relevan, dan merekan tuturan dalam peristiwa tutur tersebut.

Selain observasi, peneliti melakukan wawancara dan melakukan dokumentasi. Wawancara dipergunakan untuk mengambil informasi dengan pihakpihak terkait seperti Dosen, Ketua Jurusan, dan Mahasiswa dalam rangka 
memperoleh penjelasan tentang bahasa yang dipergunakan dalam kehidupan sehari-hari. Sedangkan dokumentasi dipergunakan untuk mengumpulkan data tentang ujaran dalam kegiatan pembelajaran yang dilakukan Dosen dan Mahasiswa STKIP Setia Budhi Rangkasbitung, baik berupa foto bahkan rekaman percakapan Mahasiswa dan Dosen.

Setelah data diperoleh dan terkumpul, peneliti transkripkan data dan mengklasifikasikanya data berdasarkan domain yang di teliti. Setelah diklasifikasikan peneliti melakukan analisis campur kode dan alih kode ujaran yang dilakukan Dosen dan Mahasiswa STKIP Setia Budhi Rangkasbitung.

Hasil analisis di simpulkan agar dapat di lihat faktor penyebab terjadinya campur kode dan alih kode. Peneliti pula menelaah buku-buku dan mencari sumber data yang berkaitan dengan masalah yang diteliti. Hal ini dilakukan agar diperolehnya keabsahan data. Keabsahan data penelitian ini diperiksa melalaui triangulasi, yaitu teknik pemeriksaan keabsahan data yang memanfaatkan sesuatu yang lain diluar data untuk keperluan pengecekan atau sebagai pembanding terhadap data tersebut. Membandingkan dan mengecek baik data kepercayaan suatu informasi dari Dosen (rekan sejawat), Mahasiswa dan pihak terkait. Diskusi bersama teman sejawat atau para kolaborator merupakan pemeriksaan keabsahan data. Selain itu, untuk memeriksa keabsahan data peneliti membandingkan antara hasil penelitian dengan informasi yang peneliti peroleh melalui hasil pengamatan dan hasil kolaborasi.

\section{TEMUAN DAN PEMBAHASAN}

Mahasiswa STKIP Setia Budhi Rangkasbitung semester 1 terdiri 27 Mahasiswa dan bahasa Ibu mereka sangat bervariasi. Mayoritas Mahasiswa menggunakan bahasa pertamanya adalah bahasa Sunda, bahasa yang dipergunakan dalam keseharian apabila berada diluar lingkungan Kampus. Namun sebagian kecil dari mereka menggunakan bahasa Indonesia, hal ini dikarenakan sebagian orang tua mereka adalah pendatang dan menetap di Rangkasbitung.

Bahasa Indonesia dipergunakan pada kegiatan belajar mengajar berlangsung, sedangkan pada saat diluar kelas bahasa yang dipergunakan Mahasiswa bergantung lawan bicara yang dihadapinya. Proses kegiatan belajar mengajar berjalan dengan lancar, dalam penyampaian materi Dosen sangat interaktif dan mampu membangkitkan motifasi belajar Mahasiswa, sehingga pada saat pembelajaran berlangsung terlihat Mahasiswa sangat antusias terhadap materi yang diajarkan dan pada akhirnya terjadi interaksi yang baik antara Dosen dan Mahasiswa.

Berdasarkan pengamatan yang penulis lakukan selama proses belajar mengajar dikelas Dosen menggunakan beberapa serpihan kata dari bahasa Sunda yang berfungsi sebagai penguat arti kata dan kalimat. Walaupun ada beberapa 
kalimat yang menggunakan bahasa Arab terlihat pada kalimat pembuka dan kalimat terakhir.

\section{Campur kode yang dilakukan Dosen dan Mahasiswa}

Campur kode yang dilakukan Dosen memang relatif rendah. Pada proses pembelajaran ditemukan 4 pencampuran kode dengan bentuk campur kode internal dan campur kode eksternal. Adapun Serpihann kata atau frasa bahasa lain yang dilakukan Dosen dalam kegiatan belajar mengajar terdapat dalam kalimat:

1) Kuduna, materi ini kita bahas minggu lalu.

2) Neng, damelkeun daftar hadir hari ini!

3) Awal kalimat aya huruf ni ageung na!

4) Jika sudah siap, tolong simpan dulu handphonenya!

Penyisipan bahasa sunda berupa kata kuduna (seharusnya), ngadamel (membuat) seharusnya masih dapat di hindari karena kata tersebut ada padanan dalam bahasa Indonesia. Penyisipan kata kuduna dan ngadamel dilakukan Dosen dengan tidak sadar, sedangkan aya huruf ni ageung na (ada huruf besarnya) merupakan bentuk campur kode berupa frasa yang diujarkan dengan sadar. Kata kuduna dan ngadamel serta frasa aya huruf ni ageung na merupakan bentuk campur kode bersifat ke dalam atau campur kode internal, karena unsur-unsur bahasanya masih tergolong satu kerabat. Berbeda dengan kata handphonenya termasuk campur kode bersifat ke luar atau campur kode eksternal, karena unsur bahasa tergolong bahasa asing yaitu bahasa Inggris.

Penggunaan serpihan kata atau frasa bahasa Sunda yang dilakukan oleh Dosen terjadi karena kebiasan Dosen melafaalkan kata-kata tersebut di dalam bahasa daerahnya, ada pula yang dilakukan secar sadar dengan tujuan untuk memperjelas arti kata atau kalimat yang di ujarkanya. Kata kata yang pengucapanya yang tidak disadari karena sudah biasa dilafalkan dalam pengucapan bahasa Sunda.

Campur kode yang dilakukan Mahasiswa semester 1 dalam kegiatan belajar di temukan 11 serpihan kata. Adapun serpihan kata yang diujarkan Mahasiswa sebagai berikut :

1) Bikin tugas Pak?

2) Diantosan Ayeuna Pak tugasnya?

3) Ngarti Pak, kahiji kalimat diawali huruf kapital, kadua diakhiri tanda baca.

4) Ditingali dulu Pak.

5) Kumaha carana ini Pak?

6) Itu tiasa

7) Permisi Pak, diantosin teman di depan.

8) Ceunah begitu Pak. 
Dalam penggunaan bahasa Indonesia, kata bikin merupakan pinjaman bahasa Sunda yang dalam bahasa Indonesia berarti membuat. Kosakata tersebut dipergunakan dalam tuturan bahasa Indonesia karena ketika tuturan orang akan berfikir dua hal apakah akan menggunakan bahasa Indonesia ataukah bahasa daerah. Keluarnya kosakata bahasa Sunda tersebut karena domain dari kosakata bahasa Indonesia.

Pencampuran kode yang sering dilakukan Mahasiswa mayoritas berbentuk kata, seperti kata bikin (membuat), kahiji (pertama), kadua (kedua), ditingali (dilihat), tiasa (bisa), diantosin (ditunggu), ceunah (katanya), tetapi ada beberapa pencampuran berupa frasa, seperti diantosin (ditunggu sekarang) dan kumaha carana (bagaimana caranya). Pencampuran yang dilakuakan Mahasiswa ini termasuk kedalam campur kode internal karena masih satu rumpun yaitu penggunaan bahasa Sunda halus dan Sunda Kasar.

Serpihan kata bahasa Sunda ke dalam bahasa Indonesia yang dilakukan oleh Mahasiswa terjadi selain karena kebiasaan melafalkan kata-kata tersebut di dalam keseharianya dalam berbagai situasi dan kondisi yang mencangkup situasi formal dan informal. Adapun dilakukan dengan sadar dengan tujuan mengakrabkan diri dengan Dosen karena persamaan latar belakang bahasa pertamanya.

Penggunaan bahasa daerah yakni bahasa Sunda yang dilakukan Dosen dan Mahasiswa terjadi karena kebiasaan. Dosen dan Mahasiswa bermaksud memperjelas arti kata atau kalimat yang mengikuti atau yang diikutinya. Foktor lainnya adalah pembendaharaan kosakata bahasa Indonesia dan lemahnya pengusaan Dosen dan Mahasiswa dalam menggunakan bahasa Indonesia.

\section{Alih kode Dosen dan Mahasiswa}

Dosen : Sudah siapkah kalian untuk belajar!

Mahasiswa : Siap pak

Dosen : Jika sudah siap, tolong simpan dulu handphonenya!

Mahasiswa : $O k$.

Dosen : Assalamualaikum Warohmatullohi Wabarokatuh.

Mahasiswa : Wa'alaikumussalam Warahmatulloh Wabarakatuh.

Dosen :Kuduna, materi ini kita bahas minggu lalu.

Mahasiswa : Tentang apa Pak?

Kutipan percakapan tersebut terjadi pada awal proses belajar mengajar. Dalam percakapan tersebut Dosen dan Mahasiswa melakukan peralihan kode. Peralihan kode yang dilakuakn dosen adalah alih kode bersifat keluar yaitu karena unsur bahasa tergolong bahasa asing yaitu bahasa Arab. Pada awal penuturan dosen menggunakan bahasa Indonesia selanjutnya dosen melakukan peralihan dengan bahasa Arab (Assalamualaikum Warohmatullohiwabarokatu). Peralihan yang 
dilakukan dosen adalah peralihan berwujud klausa karena terdiri dari subjek, predikat dan objek. Assalamualaikum sebagai subjek, Warohmatullohi sebagai Predikat dan wabarokatuh sebagai objek. Peraliahan tersebut memiliki makna semoga keselamatan dan berkah Allah SWT terlimpah kepadamu.

Berbeda peraliahan kode yang dilakukan oleh Mahasiswa. Awal percakapan Mahasiswa mnggunakan bahasa Indonesia sebagai jawaban dosen dengan menggunakan bahasa Indonesia. Selanjutnya salah satu Mahasiswa menggunakan bahasa Inggris $(\mathrm{Ok})$. Hal ini menunjukan Mahasiswa tersebut melakukan peralihan kode bersifat keluar atau alih kode eksternal.

\section{Faktor Penyebab Campur Kode dan Alih Kode}

Bedasarkan hasil analisis campur kode dan alih kode, banyak yang mempengaruhi munculnya pencampuran dan peralihan bahasa Indonesia ke bahasa daerah yakni bahasa Sunda maupun kebahasa Asing. Adapun faktor yang mempengaruhi campur kode dan alih kode yang dilakukan Mahasiswa dan Dosen sebagai berikut:

1) Kesulitan mencari padanan Kata

2) Kebiasaan

3) Kesombongan

4) Topik pembicaraan

5) Hadirnya pihak ketiga

6) Menghormati

Dalam interaksi, kekurangan kosakata banyak terjadi, hal ini disebabkan penutur tidak mengetahui suatu kata yang tepat dari bahasa Inggris dalam bahasa penutur yakni bahasa Indonesia, ataupun sebaliknya. Akibatnya penutur kemudian tetap menggunakan bahasa asli kata-kata yang tidak diketahui dalam bahasa lain yang dicampurkodekanya. Kekurangan kosakata penutur dalam suatu interaksi terkadang muncul dengan menggunakan bahasa Ibu penutur yang terkadang juga nampak seperti keragu-raguan penutur, bahkan penutur lupa untuk menggunakan kata-kata tertentu dalam bahasa lain.

Adanya topik yang lebih mudah dibicarakan dalam bahasa tertentu dibandingkan menggunakan bahasa lain. Para penutur yang memiliki dua bahasa biasanya cenderung lebih mudah membicarakan topik tertentu dalam suatu kode beralih kode lain. Penutur dwibahasa juga lebih mengalami kemudahan untuk mendiskusikan suatu topik terkait asal daerah dalam bahasa Ibu yang dipergunakan ditempat komunitas mereka tinggal. Adakalanya situasi tertentu menyebabkan seorang penutur memasuki suatu situasi percakapan dengan topik yang berbeda dari topik yang sedang dibicarakan.Ketika membicarakan suatu topik, penutur lebih merasa bahwa ia dapat menyampaikan semua hal dengan menggunakan bahasa Indonesia, beralih ke bahasa Sunda. Meskipun topik yang dibicarakan seharusnya didiskusikan dengan menggunakan bahasa Indonesia. 
Hadirnya peserta lain dalam suatu komunikasi menyebabkan peserta tutur yang sedang berinteraksi beralih kode ke bahasa lain yaitu bahasa Sunda yang dipahami oleh penutur yang datang. Hal ini dilakukan oleh penutur untuk menunjukkan bahwa penutur yang datang adalah bagian dari peristiwa tutur yang sedang terjadi. Dengan demikian pencampuran dan alih kode yang ditujukan agar penutur yang datang dapat menjadi bagian langsung dari interaksi yang sedang terjadi.

Adanya pihak lain dalam percakapan yang mengubah suatu bahasa muncul karena prinsip menghormati. Prinsip bahwa semua anggota masyarakat di dalam berbicara dan membawakan diri harus selalu menunjukkan sikap hormat terhadap orang lain sesuai dengan pangkat dan kedudukannya adalah prinsip yang telah dipegang kuat oleh masyarakat Sunda. Di dalam tingkat tutur bahasa terdapat norma, salah satunya adalah norma yang muda menghormati yang lebih tua. Menghormati orang yang lebih tua merupakan salah satu pandangan hidup manusia, terutama untuk masyarakat Indonesia. Di Indonesia, menghormati orang yang lebih tua menjadi suatu kebiasaan (tata krama) dalam kehidupan sehari- hari yang dilakukan oleh semua masyarakat, baik laki- laki maupun perempuan. Kebiasaan ini merupakan suatu kebiasaan yang baik, karena memang seharusnya orang yang lebih muda menghormati dan menghargai orang yang lebih tua.

\section{KESIMPULAN}

Banyak hal kebahasaan yang dapat dicermati dalam kehidupan sehari-hari, dan sudah merupakan hal yang tidak aneh lagi dalam konteks komunikasi langsung akan menimbulkan persinggungan antara bahasa pertama dan bahasa kedua sehingga menimbulkan gejala bahasa campur kode dan alih kode. Begitu pula penelitian yang dilakukan di STKIP Setia Budhi Rangkasbitung, penggunaan persinggungan bahasa Sunda kedalam bahasa Indonesia yang dilakukan oleh Mahasiswa dan Dosen pada proses pembelajaran terjadi secara spontan tanpa melalui proses berfikir lebih lama dan menimbulkan pencampuran system bahasa Sunda kedalam bahasa Indonesia.

\section{DAFTAR PUSTAKA}

Aslinda, \& Syafyahya. (2007). Pengantar sosiolinguitik. Bandung: PT Refika Aditama.

Chaer, A., \& Agustina. (2004). Sosiolinguistik: Perkenalan awal. Jakarta: Rhineka Cipta.

Indrawan, M. (2010). Sociolinguistics: The study of societies languages. Yogyakarta : Graha Ilmu

Rahardi, K. (2010). Sosiolinguitik: Kode dan alih Kode. Bogor: Ghalia Indonesia. Suwito, (1983). Sosiolinguistik: Teori dan problema. Surakarta: Henary offset. 